\title{
Evolutionary origin and radiation of the avian-adapted non-motile salmonellae
}

\author{
JIA LI, N. H. SMITH, KIMBERLYN NELSON, PAMELA B. CRICHTON*, D. C. OLD*, T. S. WHITTAM \\ and R. K. SELANDER $\dagger$
}

Institute of Molecular Evolutionary Genetics, Mueller Laboratory, Pennsy/vania State University, University Park, Pennsylvania 16802, USA, and "Department of Medical Microbiology, University of Dundee Medical School, Ninewells Hospital, Dundee DD1 9SY

\begin{abstract}
Summary. Multilocus enzyme electrophoresis was employed to estimate chromosomal genotypic diversity and relationships among 131 isolates of the non-motile Salmonella biotypes Gallinarum and Pullorum (serotype 1, 9, 12:-:-) that cause fowl typhoid and pullorum disease, respectively. Thirteen electrophoretic types (ETs), marking clones, were distinguished, and construction of a neighbour-joining phylogenetic tree revealed three lineages: one consisted of five ETs of Gallinarum, a second included seven ETs of Pullorum, and a third was represented by a single ET $(\mathrm{Ga} / \mathrm{Pu} 1)$ that is intermediate between those of the other two lineages in both multilocus enzyme genotype and biochemical properties. Enzyme genotype analysis and comparative nucleotide sequencing of the phase 1 flagellin gene $(f i C)$, the hook-associated protein 1 gene $(f g K)$, and the 6-phosphogluconate dehydrogenase gene $(g n d)$ identified serotype Enteritidis $(1,9,12: \mathrm{g}, \mathrm{m}:-)$ as a close relative of the non-motile salmonellae. In most strains of biotype Gallinarum, the $\mathrm{fiC}$ gene is complete, intact and identical in sequence to that of Enteritidis, but isolates of three ETs had a stop codon at position 495. The $f i C$ sequences of the ETs of Pullorum differed from that of Enteritidis in having non-synonymous changes in either two or three codons and a synonymous change in one codon. The sharing of distinctive alleles at three metabolic enzyme loci and a stop codon in $\mathrm{flgK}$ indicates that the non-motile salmonellae are monophyletic and that their most recent common ancestor was non-motile. Since diverging from that ancestor, the Pullorum lineage has evolved more rapidly than the Gallinarum and $\mathrm{Ga} / \mathrm{Pu} 1$ lineages.
\end{abstract}

\section{Introduction}

Of the more than 2200 types of Salmonella distinguished in the Kauffmann-White serological scheme of classification, ${ }^{1-3}$ only Gallinarum and Pullorum, both of which are invasive avian pathogens, ${ }^{4-6}$ are obligatorily non-flagellate and, hence, non-motile. Biotype Gallinarum is the agent of fowl typhoid, an acute septicaemic disease of pullets and adult birds involving anaemia, leucocytosis and haemorrhages in the cutis and parenchymatous organs, whereas biotype Pullorum produces bacillary white diarrhoea (pullorum disease) that affects primarily chicks in the first week of life and is characterised by diarrhoea, septicaemia and the development of caseous areas in the gizzard wall and heart muscle. Pullorum disease is commonly spread by ovarian transmission of bacteria to eggs in carrier hens, whereas infection by Gallinarum is usually acquired by the ingestion of food or water contaminated by the excreta of diseased

Received 27 April 1992; accepted 30 June 1992.

$\dagger$ Correspondence should be sent to Professor R. K. Selander. birds or carriers. Both Gallinarum and Pullorum are economically important pathogens of chickens and turkeys, but they also cause disease in others birds, and Pullorum is recovered occasionally from mammals, including man.

Because isolates of Gallinarum and Pullorum cannot be distinguished by routine serology (both are serotype $1,9,12:-:-)$, they are classified as biotypes (or bioserovars) of the same serotype $\mathrm{e}^{1,3}$ and in practice are differentiated on the basis of biotype. ${ }^{1,7,8}$ They also differ in growth characteristics, colony morphology, ${ }^{7}$ response to various bacteriophages ${ }^{9,10}$ and the expression of minor forms of somatic antigen $12 .{ }^{7}$

The present study addressed questions concerning the genetic diversity and evolution of populations of Gallinarum and Pullorum. What are the chromosomal genetic relationships of strains within and among populations? To which of the motile Salmonella serotypes are they most closely related? Are they monophyletic or polyphyletic? And even if monophyletic, was the non-motile condition a property of their most recent common ancestor or did it develop independently in separate lineages derived from that 
ancestor? Have the flagellin-encoding gene and other genes mediating the expression of flagella been lost or only silenced?

In an attempt to answer these questions, we have analysed strains of Gallinarum and Pullorum for protein polymorphisms by multilocus enzyme electrophoresis and for DNA polymorphisms by nucleotide sequencing of the $\mathrm{flC}$ gene encoding phase 1 flagellin and the gnd gene encoding the metabolic enzyme 6phosphogluconate dehydrogenase.

\section{Materials and methods}

\section{Bacteria}

A collection of 131 strains previously identified as either Gallinarum or Pullorum in the collections of the Department of Medical Microbiology, University of Dundee Medical School, and the Institute für Veterinarmedizin des Bundesgesundheitsamtes, Berlin, Germany, including 86 strains that were earlier analysed for variation in biotype,$^{11}$ was examined. For several isolates exhibiting unusual multilocus enzyme genotypes or biochemical properties, serotyping and biotyping were repeated by Ms K. E. Ferris at the National Veterinary Services Laboratories, Ames, IA, USA.

The sources of the isolates were the USA ( 9 isolates), Canada (1), Brazil (1), Ecuador (2), the UK (44), Germany (32), Denmark (1), Greece (11), the Middle East (12), Kenya (6), Tanzania (7), Australia (1) and unknown (4). The isolates were collected in the period 1921-1987.

\section{Electrophoresis of enzymes}

Methods of lysate preparation, protein electrophoresis, and selective enzyme staining were as described by Selander et al. ${ }^{12}$ Variation in electrophoretic mobility of the following 23 enzymes was assayed in all 131 isolates: isocitrate dehydrogenase (IDH), aconitase $(\mathrm{ACO})$, carbamylate kinase (CAK), adenylate kinase (ADK), 6-phosphogluconate dehydrogenase (6PG), phosphoglucose isomerase (PGI), nucleoside phosphorylase-1 (NP1), catalase (CAT), hexokinase (HEX), leucylglycyl-glycine peptidase (LGG), phenylalanyl-leucine peptidase (PLP), malate dehydrogenase (MDH), glucose-6-phosphate dehydrogenase (G6P), mannitol-1-phosphate dehydrogenase (M1P), glucose dehydrogenase (GDH), phosphoglucomutase (PGM), glutamate dehydrogenase (GLU), indophenol oxidase (IPO). mannose-6-phosphate isomerase (MPI), glutamic-oxaloacetic transaminase-1 (GT1), shikimate dehydrogenase (SKD), acid phosphatase-1 (AP1) and acid phosphatase-2 (AP2).

Electromorphs (allozymes) of each enzyme were equated with alleles at the corresponding structural gene locus, and an absence of enzyme activity was attributed to a null allele. Distinctive combinations of alleles (multilocus enzyme genotypes) were designated as electrophoretic types (ETs). ${ }^{12}$

Single isolates of the ETs which were identified by analysis of the 23 enzyme loci were further characterised for alleles at loci encoding the following six enzymes: malic enzyme (MAE), nucleoside phosphorylase-2 (NP2), glyceraldehyde-3-phosphate dehydrogenase (G3P), threonine dehydrogenase (THD), alkaline phosphatase-1 (AL1) and alkaline phosphatase2 (AL2).

For comparative purposes, representative single isolates of 12 of the ETs of Salmonella Enteritidis identified by Beltran et $a l^{13}$ and eight other serotypes of Salmonella subspecies $\mathrm{I}^{2}$ were analysed for allelic variation at all 29 enzyme loci.

The antigenic formulae of the serotypes and biotypes studied are given in table $\mathrm{I}$.

\section{Biotyping}

A description of methods was given by Crichton and Old, ${ }^{11}$ who biotyped 86 of the non-motile isolates. The traits examined were: production of gas from glucose; fermentation of dulcitol, maltose, rhamnose and xylose; and decarboxylation of ornithine.

\section{Southern hybridisation of the flagellin ( $f i C)$ gene}

Chromosomal DNA prepared by the method of Wilson ${ }^{14}$ was double-digested with EcoRI and HindIII and tested in Southern hybridisation with a probe consisting of a 388-bp segment (bp 66-453) of the fliC gene of serotype Typhimurium. ${ }^{15}$

\section{Cloning of the fiC gene of Gallinarum}

From the DNA of a strain of Gallinarum ET Ga 2 (RKS 4994), a 4.4-kb EcoRI-HindIII fragment that hybridised with the flagellin-gene probe was cloned; and from four subclones, a $2-\mathrm{kb}$ fragment that included the $\mathrm{fiC}$ gene and its flanking regions was sequenced.

\section{PCR-amplification and comparative sequencing of fliC and gnd}

Single-stranded templates for sequencing the $f i C$ and gnd genes were generated by $\mathrm{PCR}^{16}$ and the $\lambda$ exonuclease method. ${ }^{17}$ Both orientations were sequenced by the Sequenase Version 2.0 protocol (United States Biochemical Corporation, Cleveland, $\mathrm{OH}, \mathrm{USA}$ ), and the data were assembled and edited with the SEQMAN and SEQMANED programs (DNASTAR, Madison, WI, USA).

Primers for the amplification of a 1916-bp fragment containing the complete coding region of the $\mathrm{fiC}$ gene, $285 \mathrm{bp}$ of the $5^{\prime}$ flanking sequence, and $113 \mathrm{bp}$ of the downstream region were designed from the sequence of RKS 4994 (table II). With the aid of four sets of internal primers (table II), this segment was sequenced 
Table I. Antigenic formulae of Salmonella serotypes and biotypes studied

\begin{tabular}{|c|c|c|c|c|}
\hline \multirow{2}{*}{ Serotype or biotype } & \multirow{2}{*}{$\begin{array}{c}\text { Representative } \\
\text { ET }\end{array}$} & \multicolumn{3}{|c|}{ Antigenic factors } \\
\hline & & $\mathrm{O}$ & $\mathrm{H} 1$ & $\mathrm{H} 2$ \\
\hline Gallinarum & $\mathrm{Ga} 2$ & $1,9,12$ & - & \\
\hline Pullorum & $\mathrm{Pu} 3$ & $\overrightarrow{1}, 9,12$ & - & - \\
\hline Gallinarum/Pullorum* & $\mathrm{Ga} / \mathrm{Pu} 1$ & $\underline{\mathbf{1}}, 9,12$ & - & - \\
\hline Enteritidis & En 1 & $\overrightarrow{1}, 9,12$ & $\mathrm{~g}, \mathrm{~m}$ & - \\
\hline Dublin & Du 1 & $\underline{1}, 9,12$ & $\mathrm{~g}, \mathrm{p}$ & \\
\hline Newmexico & $\mathrm{Nm} 1$ & $\overline{9}, 12$ & $\mathrm{~g}, \mathrm{z} 51$ & 1,5 \\
\hline Elomrane & El 1 & $1,9,12$ & z38 & - \\
\hline Montevideo & Mo 1 & $6,7,14$ & $\mathrm{~g}, \mathrm{~m}, \mathrm{~s}$ & - \\
\hline Senftenberg & Sf 1 & $1,3,19$ & $\mathrm{~g}, \mathrm{~s}, \mathrm{t}$ & - \\
\hline Derby & De 13 & $1,4,[5], 12$ & f, g & 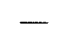 \\
\hline Typhimuri & $\operatorname{Tm} 1$ & $\underline{1}, 4,[5], 12$ & $\mathrm{i}$ & \\
\hline Heidelberg $\dagger$ & He 1 & $\underline{1}, 4,[5], 12$ & $\mathrm{r}$ & 1,2 \\
\hline Pensacola & Pe 1 & 9,12 & $\mathrm{~m}, \mathrm{t}$ & \\
\hline
\end{tabular}

$\mathrm{O}$, somatic polysaccharide; $\mathrm{H} 1$, phase 1 flagella; $\mathrm{H} 2$, phase 2 flagella. Underlined $\mathrm{O}$ factors are expressed as a result of phage conversion; [ ] factors not expressed by all isolates.

* Organisms representing ET Ga/Pu 1 were previously identified as Pullorum on the basis of biotype traits, but phylogenetically they are more closely allied with Gallinarum (see text).

$\dagger$ The gnd gene of a strain of Heidelberg was sequenced (see Materials and methods), but this strain was not included in the analysis of multilocus enzyme electrophoresis or other aspects of the present study.

in nine strains of the non-motile salmonellae and eight strains of serotype Enteritidis.

A 1399-bp fragment containing virtually all of the coding region of the gnd gene was amplified with primers designed from the published sequences for Typhimurium LT2 ${ }^{18}$ and Escherichia coli $\mathrm{K} 12,{ }^{19}$ as follows:

\section{5'primer: 5'GTCCAAGCAACAGATCGGCG- TAGTCGGTAT- $3^{\prime}$ 3'primer: 5'-CCAACCATTCGGTATGGAAAA- CGCCTTCTTTATC-3'}

The gnd genes of strains of eight serotypes or biotypes, including Ga 2 (RKS 4994), Pu 3 (RKS 5078), Ga/Pu 1 (RKS 5079), Enteritidis En 1 (RKS
53), Dublin Du 1 (RKS 4699), Typhimurium Tm 1 (RKS 284), Heidelberg He 1 (RKS 539), and Derby De 13 (RKS 241), were sequenced with the aid of five sets of internal primers (K.N. and R.K.S., unpublished observations).

The sequences reported here have been assigned GenBank accession numbers M84974-M84980.

\section{Results}

\section{Genetic diversity}

Of the 23 enzyme loci assayed for allelic variation by enzyme electrophoresis in 131 non-motile salmonellae, 12 loci were polymorphic and 11 loci were monomorphic (table III). Thirteen distinctive multilocus genotypes, designated as electrophoretic types (ETs), were identified.

Among the 56 strains identified by biotype as Gallinarum, five ETs were distinguished, pairs of which differed in alleles at from one to three of the 23 enzyme loci assayed (table III). Ga 2 was represented by 34 isolates, including one strain (RKS 5058; original strain number SL303) which had been received as an atypical strain of Pullorum by Crichton and Old ${ }^{11}$ but whose biotype proved to be more like that of strains of Gallinarum. Isolates of $\mathrm{Ga} 2$ were originally isolated in the USA, Ecuador, the UK, Greece, the Middle East, Kenya and Tanzania in the period 1921-1986. Ga 2a, which differs from Ga 2 in having null alleles at the AP1 and AL2 loci, was represented by 18 isolates collected in the Middle East, Greece and the UK. The three remaining ETs, Ga 1, Ga 3 and $\mathrm{Ga} 4$, each of which was represented by only one or two isolates, differed from $\mathrm{Ga} 2$ at one or two loci.

Among the 75 strains received as Pullorum (excluding RKS 5058, mentioned above), eight distinct multilocus genotypes were distinguished, seven of which were designated as ETs of Pullorum $(\mathrm{Pu})$; the eighth ET was designated as $\mathrm{Ga} / \mathrm{Pu} 1$ for reasons

Table II. Primers used for PCR-amplification and sequencing of $f i C$

\begin{tabular}{|c|c|c|}
\hline Primer* & Nucleotide sequence & $5^{\prime}$ start position $\dagger$ \\
\hline \multicolumn{3}{|l|}{$5^{\prime}$ to $3^{\prime}$} \\
\hline G1 & 5'-CCCACACCTAATGATGAAATTGAAGC-3' & -285 \\
\hline G3 & 5'-AAAGGTCTGACTCAGGCT- $3^{\prime}$ & +175 \\
\hline G5 & 5'-ATCCAGGTTGGTGCCAAC-3' & +436 \\
\hline G7 & 5'-TGGTAAGGAAGGAGATAC- $3^{\prime}$ & +807 \\
\hline G9 & 5'-TCACCTTAGCTGGCAAAA-3' & +1151 \\
\hline \multicolumn{3}{|c|}{ 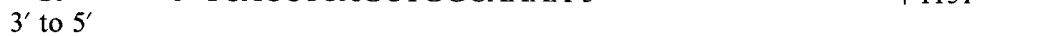 } \\
\hline $\mathrm{G} 2$ & 5'-ACAAAGGCAGGTTCAGTGA-3' & +1631 \\
\hline G4 & $5^{\prime}$-TTGAATTGCCCCCAGAGA-3' & +1320 \\
\hline G6 & 5'-TGACCGTTCACTACAGAT-3' & +1016 \\
\hline G8 & 5'-TTCCGCATCGTCAGTTGT-3' & +720 \\
\hline G10 & 5'-GTTGGCACCAACCTGGAT-3' & +453 \\
\hline
\end{tabular}

* Primers G1, G5, and G10 were designed from the published $f i C$ sequence of Typhimurium, ${ }^{15,45}$ and the other primers were designed from the sequence of the cloned gene of Gallinarum (this study).

$\dagger$ Relative to the adenine (position +1 ) residue of the ATG start codon. 
Table III. Allele profiles of ETs of Enteritidis, Gallinarum, Pullorum and Gallinarum/Pullorum

\begin{tabular}{|c|c|c|c|c|c|c|c|c|c|c|c|c|c|c|c|c|c|c|c|c|c|c|c|c|c|}
\hline \multirow{2}{*}{ ET } & \multirow{2}{*}{$\begin{array}{l}\text { Number } \\
\text { of isolates }\end{array}$} & \multicolumn{24}{|c|}{ Allele at indicated enzyme locus* } \\
\hline & & IDH & $\mathrm{ACO}$ & CAK & PGI & $\mathrm{NPI}$ & CAT & HEX & LGG & PLP & MDH & G6P & $\mathbf{M} 1 \mathbf{P}$ & PGM & GLU & IPO & MPI & GT1 & SKD & $\mathrm{APl}$ & AP2 & NP2 & G3P & THD & AL2 \\
\hline En 1 & 1 & 3 & 3 & 3 & 3 & 3 & 3 & 3 & 3 & 3 & 3 & 3 & 3 & 3 & 3 & 3 & 3 & 3 & 0.5 & 3 & 5 & 3 & 3 & 3 & 3 \\
\hline En 3 & 1 & . & & 2 & & & . & & . & 2.5 & . & . & . & & 5 & 4 & . & . & . & . & & . & . & . & . \\
\hline En 4 & 1 & . & . & 2 & . & & . & & & & . & & . & & 5 & 4 & & & & & . & & . & . & . \\
\hline En 5 & 1 & & & 2 & & & 0 & & . & & & & . & & & . & & . & . & . & & . & . & . & . \\
\hline En 7 & 1 & & . & . & & & 2.5 & . & . & & . & & 5 & . & . & . & . & . & 1 & . & 7 & 5 & . & . & . \\
\hline En 9 & 1 & & & & & & . & 2 & . & . & . & 1 & . & . & . & . & . & . & . & & . & . & 5 & . & . \\
\hline En 10 & 1 & & & . & . & & 25 & & . & & . & & . & . & . & . & & & 1 & & . & 4 & . & . & . \\
\hline En 12 & 1 & & . & . & & & 1 & . & . & . & . & & & . & & . & & . & . & & . & 0 & . & . & . \\
\hline En 14 & 1 & & & & & . & . & . & . & . & . & & . & . & 4 & . & . & . & . & & & . & . & . & \\
\hline En 15 & 1 & 2 & . & & . & . & . & . & . & . & & & . & . & & . & . & . & . & . & . & . & . & . & . \\
\hline En 17 & 1 & . & . & . & & . & & . & . & & . & $2 \cdot 5$ & . & & . & . & . & & . & . & & . & . & & . \\
\hline En 2 & 1 & & 4 & & & 9 & 1.5 & . & 5 & . & . & . & 0.5 & 2 & . & . & 2 & . & 1 & 5 & 14 & 4 & . & . & 9 \\
\hline $\mathrm{Ga} 1$ & 1 & & & & 5 & 3.2 & 2 & . & . & . & 7 & & . & . & & . & . & & . & . & 0 & . & . & 2 & . \\
\hline $\mathrm{Ga} 2$ & 34 & & & & 5 & 3.2 & & . & & & 7 & & . & . & . & & & & . & & 0 & & . & 2 & \\
\hline Ga $2 a$ & 18 & & . & . & 5 & $3 \cdot 2$ & . & . & & . & 7 & & . & . & & . & . & . & . & 0 & 0 & . & . & 2 & 0 \\
\hline $\mathrm{Ga} 3$ & 1 & & & . & 5 & $3 \cdot 2$ & 4 & . & . & . & 7 & . & . & . & & & . & . & . & & 0 & & & 2 & . \\
\hline Ga 4 & 2 & & . & . & $s$ & $3 \cdot 2$ & & 5 & . & . & 7 & 5 & . & . & . & . & . & . & . & . & 0 & . & . & 2 & $\cdot$ \\
\hline $\mathrm{Ga} / \mathrm{Pu}$ & 13 & & 4 & . & 5 & $3 \cdot 2$ & 4 & & . & . & . & . & . & . & . & . & . & . & . & . & . & . & . & 2 & . \\
\hline $\mathrm{Pu} 1$ & 1 & & 2.5 & & 5 & $3 \cdot 2$ & & & 4 & . & . & . & & 5 & . & . & & 2 & . & 0 & . & . & . & 2 & 0 \\
\hline $\mathrm{Pu} 2$ & 16 & & 2.5 & . & 5 & $3 \cdot 2$ & . & & 4 & & . & 2.5 & . & . & . & . & . & 2 & . & 0 & . & . & . & 2 & 0 \\
\hline $\mathrm{Pu} 3$ & 29 & . & $2 \cdot 5$ & & 5 & $3 \cdot 2$ & & . & 4 & . & . & . & & . & . & . & . & 2 & . & 0 & . & . & . & 2 & 0 \\
\hline Pu 3it & 6 & . & $2 \cdot 5$ & . & 5 & $3 \cdot 2$ & & & 4 & & & & . & & 0 & . & & 2 & . & 0 & . & . & . & 2 & 0 \\
\hline Pa $3 b$ & 2 & & 2.5 & & 5 & 0 & & & 4 & . & . & & . & . & . & . & . & 2 & . & 0 & . & . & . & 2 & 0 \\
\hline $\mathrm{Pu} 3 \mathrm{c}$ & 1 & & 2.5 & . & 5 & 0 & . & . & 4 & . & . & . & . & & . & & . & 2 & . & 0 & 0 & . & . & 2 & 0 \\
\hline Pu 4 & 7 & & 2.5 & . & 5 & 4.9 & . & & 4 & . & . & & . & . & . & & . & 2 & . & 0 & . & . & . & 2 & 0 \\
\hline
\end{tabular}

See Materials and methods for names of enzymes. Dots indicate identity.

*An additional five loci were monomorphic (each for a 3 allele), as follows: ADK, 6PG, GDH, MAE and AL1.

Table IV. Allele profiles of single ETs of eight Salmonella serotypes

\begin{tabular}{|c|c|c|c|c|c|c|c|c|c|c|c|c|c|c|c|c|c|c|c|}
\hline \multirow{2}{*}{ ET } & \multicolumn{19}{|c|}{ Allele at indicated enzyme locus* } \\
\hline & IDH & $\mathrm{ACO}$ & $6 \mathrm{PG}$ & PGI & NPl & CAT & HEX & LGG & PLP & G6P & $\mathbf{M} 1 \mathbf{P}$ & PGM & MPI & GT 1 & SKD & AP1 & AP2 & NP2 & ALl \\
\hline Du 1 & 3 & 3 & 3 & 3 & 3 & 3 & 3 & 3 & 3 & 3 & 3 & 4 & 3 & 3 & 1 & 3 & 5 & 5 & 3 \\
\hline De 13 & 2 & 3 & 5 & 3 & 5 & 2 & 3 & 3 & 3 & 3 & 3 & 3 & 3 & 3 & 1 & 3 & 11 & 3 & 3 \\
\hline Mo \& & 5 & 3 & 3 & 3 & 5 & 3 & 5 & 4 & 4 & 5 & 2 & 2 & $2 \cdot 5$ & 3 & 1 & 3 & 14 & 0 & 3 \\
\hline Sf 1 & 3 & 4 & 3 & 3 & 5 & 3 & 3 & 3 & 4 & 3 & 3 & 3 & 3 & 2 & 1 & 3 & 3 & 1 & 3 \\
\hline El 1 & 3 & 4 & 3 & 3 & 5 & 5 & 3 & 3 & 3 & 3 & 3 & 2 & 3 & 3 & 6 & 3 & 0 & 5 & 3 \\
\hline Pe 1 & 2 & 3 & 3 & 3 & 5 & 4 & 3 & 3 & 2 & 3 & 3 & 3 & 3 & 3 & 1 & 5 & 10 & 3.5 & 5 \\
\hline $\mathrm{Nm} 1$ & 3 & 3 & 2 & 2 & 5 & 0 & 3 & 2 & 3 & 3 & 2 & 3 & 5 & 3 & 1 & 3 & 0 & 5 & 3 \\
\hline $\mathrm{Tm} 1$ & 3 & 3 & 2 & 3 & 7 & 3.5 & 3 & 3 & 3 & 3 & 3 & 3 & 3 & 3 & 0.5 & 3 & 10 & 5 & 3 \\
\hline
\end{tabular}

See Materials and methods for names of enzymes.

* Ten additional loci were monomorphic (each for a 3 allele): CAK, ADK, MDH, GDH, GLU, IPO, MAE, G3P, THD and AL2.

given below. Two of the Pullorum ETs, Pu 2 and $\mathrm{Pu} 3$ that differed at only one locus, were represented by 16 and 29 isolates, respectively. Strains of $\mathrm{Pu} 3$ were isolated in the USA, Canada, Brazil, the UK, Denmark, Germany and Australia between 1939 and 1987. and all isolates of $\mathrm{Pu} 2$ were from the UK. $\mathrm{Pu} 3 \mathrm{a}$, $\mathrm{Pu} 3 \mathrm{~b}$, and $\mathrm{Pu} 3 \mathrm{c}$, which differed from $\mathrm{Pu} 3$ in having null alleles at one or two loci, were each represented by from one to six isolates. $\mathrm{Pu} 1$ and $\mathrm{Pu} 4$ were represented by one and seven isolates, respectively, from Germany.

ET Ga/Pu 1, which was represented by 12 isolates from Germany and one from the Middle East, had a distinctive allele at the ACO locus, but, otherwise, its enzyme genotype was a combination of alleles that distinguished the common ETs of Gallinarum and Pullorum (table III). Thus, $\mathrm{Ga} / \mathrm{Pu} 1$ was like Gallinarum in carrying the $\mathrm{LGG}^{3}, \mathrm{GT}^{3}, \mathrm{AP}^{3}$, and $\mathrm{AL}^{3}$ alleles but shared the $\mathrm{MDH}^{3}$ and $\mathrm{AP} 2^{5}$ alleles with Pullorum.

\section{Evolutionary relationships among ETS}

From profiles of alleles at 29 enzyme loci (tables III and IV), estimates of Nei's standard genetic distance ${ }^{20}$ were obtained for all pairs of the 13 ETs of the nonmotile salmonellae, 12 ETs of Enteritidis, and single ETs of eight other Salmonella serotypes. A neighbourjoining tree ${ }^{21}$ based on these distances is shown in fig. 1. For the purposes of the present study, the important 


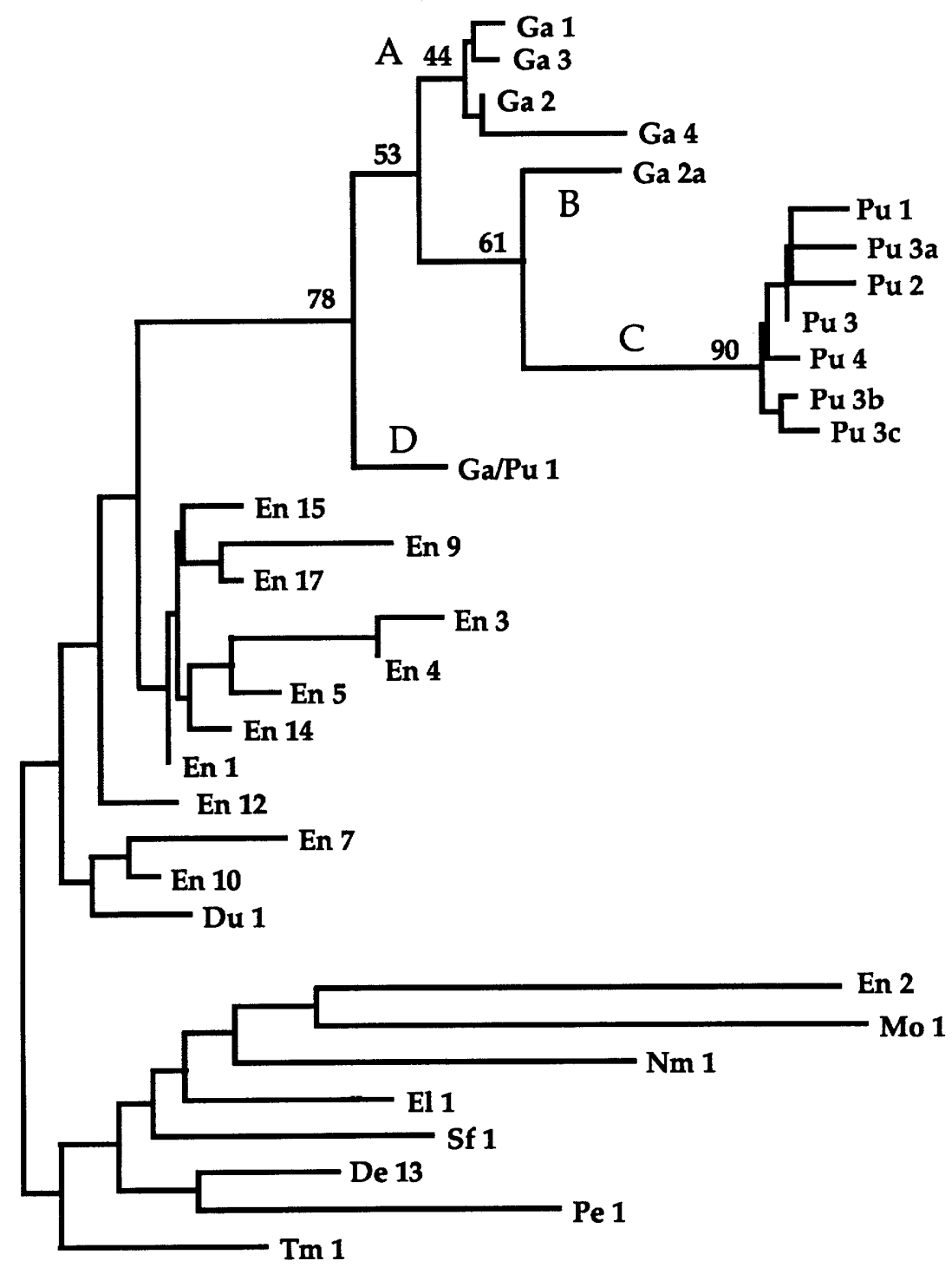

Genetic distance

0.1

Fig. 1. Evolutionary tree for ETs of the non-motile salmonellae, Enteritidis, and eight other subspecies I serotypes, constructed by the neighbour-joining method from a matrix of pairwise estimates of Nei's standard genetic distance based on allelic variation at 29 enzyme loci. For ETs of the non-motile salmonellae, the significance of the branching order, as determined by bootstrap analysis of 1000 computergenerated trees, is indicated by the numbers at the nodes. Lineages of the non-motile salmonellae are labelled A-D. De, Derby; Du, Dublin; En, Enteritidis; El, Elomrane; Ga, Gallinarum; Ga/Pu, Gallinarum/Pullorum; Mo, Montevideo; Nm, Newmexico; Pe, Pensacola; Pu, Pullorum; Sf, Senftenberg; and Tm, Typhimurium.

aspect of the tree was that all the ETs of the non-motile salmonellae clustered together with 11 of the 12 ETs of Enteritidis (the exception was En 2) and the ET of Dublin (Du 1). ETs of Newmexico (Nm 1), Elomrane (El 1), Montevideo (Mo 1), Senftenberg (Sf 1), Derby (De 13), Typhimurium (Tm 1), and Pensacola (Pe 1), and En 2 were more distantly related. The primary distinction between the multilocus genotypes of the ETs of Enteritidis and those of the non-motile salmonellae was the occurrence of different alleles at the PGI, NP1, and THD loci (table III).

ETs of the non-motile strains occurred in four lineages, designated A, B, C and D in fig. 1. Lineage A included four of the five ETs (Ga 1, Ga 2, Ga 3 and $\mathrm{Ga} 4$ ) that represent classical Gallinarum. Lineage B consisted of $\mathrm{Ga} \mathrm{2a}$, which, because of the occurrence of null alleles at the AP1 and AL2 loci, clustered with the seven Pu ETs of lineage $\mathrm{C}$, representing classical Pullorum. The D lineage was that of ET Ga/Pu 1 .

\section{Variation in biotype}

Variation in six biochemical traits within and among ETs is shown in table V. As noted by Crichton and Old, ${ }^{11}$ isolates of Gallinarum were all but invariant in biotype, whereas those of Pullorum exhibited several combinations of biochemical traits. $\mathrm{Ga} / \mathrm{Pu} 1$ resembled classical Pullorum in producing gas and being ornithine decarboxylase positive, but, like classical Gallinarum, it was dulcitol positive and rhamnose negative; only one isolate of this ET was represented in the sample of isolates studied by Crichton and Old. ${ }^{11}$ 
Table V. Variation in biochemical traits within and among ETs of non-motile salmonellae

\begin{tabular}{|c|c|c|c|c|c|c|c|}
\hline \multirow{3}{*}{$\mathrm{ET}^{*}$} & \multirow{3}{*}{$\begin{array}{c}\text { Number of } \\
\text { isolates }\end{array}$} & \multicolumn{6}{|c|}{ Percentage of isolates that gave positive results for } \\
\hline & & \multirow{2}{*}{$\begin{array}{c}\text { gas } \\
\text { production }\end{array}$} & \multicolumn{4}{|c|}{ fermentation of } & \multirow{2}{*}{$\begin{array}{c}\text { ornithine } \\
\text { decarboxylation }\end{array}$} \\
\hline & & & dulcitol & maltose & rhamnose & xylose & \\
\hline Ga $1-4$ & 53 & 0 & 100 & 98 & 2 & NT & 0 \\
\hline $\mathrm{Ga} / \mathrm{Pu} 1$ & 4 & 100 & $100 \dagger$ & 50 & $0 \ddagger$ & $0 \ddagger$ & 100 \\
\hline $\mathrm{Pu} 1$ & 1 & 100 & 0 & 0 & NT & NT & 100 \\
\hline Pu 3 & 12 & 42 & 0 & 0 & 58 & 58 & 100 \\
\hline $\mathrm{Pu} 3 \mathrm{a}$ & 6 & 100 & 0 & 0 & 100 & 100 & 100 \\
\hline $\mathrm{Pu} 2$ & 16 & 31 & 0 & 0 & 25 & 25 & 100 \\
\hline $\mathrm{Pu} 4$ & 1 & 100 & 0 & 0 & NT & NT & 100 \\
\hline
\end{tabular}

NT, not tested.

* Isolates of ETs Pu $3 \mathrm{~b}$ and $\mathrm{Pu} 3 \mathrm{c}$ were not tested.

+ Five isolates tested.

$\ddagger$ One isolate tested.

Table VI. Variation in nucleotide sequence of the $f i C$ gene

\begin{tabular}{|c|c|c|c|c|c|c|c|c|}
\hline \multirow{2}{*}{$\begin{array}{l}\text { Strain } \\
\text { no. }\end{array}$} & \multirow{2}{*}{ ET } & \multicolumn{7}{|c|}{ Codon at indicated polymorphic position } \\
\hline & & 53 & 55 & 91 & 316 & 339 & 431 & 495 \\
\hline RKS 53 & En 1 & $\begin{array}{c}\text { Arg } \\
\text { CGC }\end{array}$ & $\begin{array}{c}\text { Thr } \\
\text { ACT }\end{array}$ & $\begin{array}{c}\text { Arg } \\
\text { CGT }\end{array}$ & $\begin{array}{c}\text { Gly } \\
\text { GGC }\end{array}$ & $\underset{\text { CAG }}{\text { Glu }}$ & $\underset{\text { GCA }}{\text { Ala }}$ & $\begin{array}{c}\text { Gly } \\
\text { CAG }\end{array}$ \\
\hline RKS 69 & En 3 & $\ldots$ & $\ldots$ & $\cdots$ & $\cdots$ & $\cdots$ & $\ldots$ & $\ldots$ \\
\hline RKS 74 & En 5 & $\ldots$ & $\ldots$ & $\ldots$ & $\ldots$ & $\ldots$ & $\ldots$ & $\ldots$ \\
\hline RKS 1208 & En 7 & $\ldots$ & $\ldots$ & $\ldots$ & $\ldots$ & $\ldots$ & $\ldots$ & $\ldots$ \\
\hline RKS 30 & En 14 & $\ldots$ & $\ldots$ & $\cdots$ & $\cdots$ & $\cdots$ & $\cdots$ & $\cdots$ \\
\hline RKS 119 & En 15 & $\ldots$ & $\ldots$ & $\ldots$ & $\ldots$ & $\ldots$ & $\cdots$ & $\cdots$ \\
\hline RKS793 & En 17 & $\cdots$ & $\cdots$ & $\cdots$ & Ser & $\cdots$ & $\cdots$ & $\cdots$ \\
\hline RKS 761 & En 2 & $\ldots T$ & $\ldots \mathrm{G}$ & $\ldots$ & A. & $\ldots$ & $\ldots$ & $\hat{A m b}$ \\
\hline RKS 5029 & Ga 1 & $\ldots$ & $\cdots$ & $\cdots$ & $\ldots$ & $\ldots$ & $\ldots$ & $\mathrm{T}$. \\
\hline RKS 4994 & $\mathrm{Ga} 2$ & $\ldots$ & $\ldots$ & $\ldots$ & $\cdots$ & $\ldots$ & $\ldots$ & T. . \\
\hline RKS 4996 & Ga 3 & $\ldots$ & $\cdots$ & $\ldots$ & $\ldots$ & $\ldots$ & $\ldots$ & $\ldots$ \\
\hline RKS 5021 & $\mathrm{Ga} 4$ & $\cdots$ & $\cdots$ & $\cdots$ & $\cdots$ & $\cdots$ & $\cdots$ & $\cdots$ \\
\hline RKS 5079 & $\mathrm{Ga} / \mathrm{Pu} 1$ & $\cdots$ & . & $\ddot{\text { Ser }}$ & $\cdots$ & Lys & $\cdots$ & $\cdots$ \\
\hline RKS 5049 & $\mathrm{Pu} 2$ & $\ldots$ & . & $\begin{array}{l}\text { A. } \\
\text { Ser }\end{array}$ & $\ldots \mathrm{A}$ & $\begin{array}{l}\text { A. } \\
\text { Lys }\end{array}$ & Thr & $\cdots$ \\
\hline RKS 2249 & $\mathrm{Pu} 1$ & $\ldots$ & . & A. . & $\ldots \mathrm{A}$ & A. . & A. . & $\ldots$ \\
\hline RKS 5078 & Pu 3 & $\ldots$ & $\ldots$ & A. . & $\ldots \mathbf{A}$ & A. . & A. . & $\ldots$ \\
\hline RKS 2242 & $\mathrm{Pu} 4$ & $\ldots$ & $\ldots$ & A. . & $\ldots \mathrm{A}$ & A. . & A.. & $\ldots$ \\
\hline
\end{tabular}

\section{Flagellin ( $\mathrm{fliC}$ ) genes in non-motile strains}

To determine whether $f i C$ genes are present in the genomes of the non-motile salmonellae, EcoRI$H$ indIII-digested chromosomal DNA from two isolates of Gallinarum (representing $\mathrm{Ga} 2$ and $\mathrm{Ga} 4$ ), three isolates of Pullorum (Pu 2, $\mathrm{Pu} 3$ and $\mathrm{Pu}$ 4), and an isolate of Gallinarum/Pullorum $(\mathrm{Ga} / \mathrm{Pu} 1)$ was tested with a flagellin gene probe in Southern hybridisations. In all six isolates, a $4 \cdot 4-\mathrm{kb}$ fragment hybridised with the probe, indicating the presence of at least part of the $\mathrm{AiC}$ gene. The gene was then sequenced in strains of the non-motile salmonellae and Enteritidis.

\section{Variation in sequence of the fiC coding region}

The nucleotide sequences of the 1518-bp $\mathrm{AiC}$ coding region were identical in isolates of $\mathrm{Ga} 3, \mathrm{Ga} 4$,
$\mathrm{Ga} / \mathrm{Pu} 1$ and seven of the eight ETs of Enteritidis (table VI). (For convenience of discussion, we have designated this sequence as the standard.) The exceptional ET of Enteritidis was En 2, which differed markedly in multilocus enzyme genotype from all other ETs of that serotype ${ }^{13}$ (see table III and below).

The $f i C$ gene of $\mathrm{Ga} 2$ isolate RKS 4994 differed from the standard sequence at a single site that created a stop codon at amino acid position 495 (table VI); and the same stop codon was present in the sequence of isolate RKS 5029, representing Ga 1 . To further determine the distribution of this mutation, a 400-bp $\mathrm{fiC}$ segment that included codon 495 was sequenced in three additional isolates of $\mathrm{Ga} 2$ and a strain of $\mathrm{Ga} 2 \mathrm{a}$ (data not shown). Only the Ga 2a strain had this stop codon. It is noteworthy that all three isolates with the stop codon were isolated in the Middle East. 


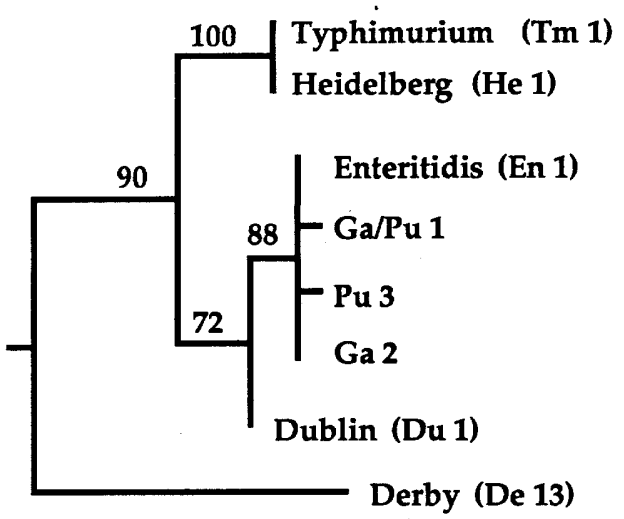

Genetic distance

Fig. 2. Evolutionary tree for the gnd nucleotide sequences of single strains of eight Salmonella serotypes and biotypes constructed by the neighbour-joining method. The significance of the branching order, as determined by bootstrap analysis of 1000 computergenerated trees, is indicated by the numbers at the nodes.

The $f i C$ genes of four strains of Pullorum (representing $\mathrm{Pu} 1, \mathrm{Pu} 2, \mathrm{Pu} 3$ and $\mathrm{Pu}$ 4) differed from the standard sequence by three or four nucleotides (table VI). All four strains had non-synonymous substitutions in codons $91(\mathrm{Arg} \rightarrow \mathrm{Ser})$ and 339 (Glu $\rightarrow$ Lys) and a synonymous change in codon 316 . In addition, strains of $\mathrm{Pu} 1, \mathrm{Pu} 3$ and $\mathrm{Pu} 4$ shared a non-synonymous change in codon 431 (Ala $\rightarrow$ Thr).

\section{Nucleotide polymorphism in gnd}

Among the eight subspecies I strains from which a 1335-bp segment of the gnd coding region was sequenced, there were 28 polymorphic nucleotide sites. The sequence of Ga 2 strain RKS 4994 was identical to that of Enteritidis En 1 strain RKS 53, and the sequences of isolates of $\mathrm{Pu} 3$ (RKS 5078) and Ga/Pu 1 (RKS 5079) were distinctive only in having single unique synonymous changes. In contrast, Tm 1 (RKS 284) differed from Ga 2 and En 1 in having one nonsynonymous and eight synonymous changes.

A neighbour-joining tree generated from these data is shown in fig. 2. The evolutionary relationships of the strains indicated by the gnd locus sequences are the same as those shown by a tree based on multilocus enzyme genotype (fig. 1), with the non-motile salmonellae clustering together with Enteritidis and Dublin.

\section{Discussion}

\section{Clonal structure of populations}

The recovery of isolates of identical ET in widely separated regions and over periods as long as 50 years ( $\mathrm{Ga} 2$ and $\mathrm{Pu} 3$ ) indicates that the genetic structure of populations of Gallinarum and Pullorum is basically clonal, as previously demonstrated for the salmonellae in general. ${ }^{13,22,23}$ Natural populations of Gallinarum are composed predominantly of strains of one clone,
Ga 2, which is global in distribution; $52(93 \%)$ of the 56 isolates of the Gallinarum lineage represent $\mathrm{Ga} 2$ or $\mathrm{Ga} 2 \mathrm{a}$, which is distinctive only in having null alleles at two loci and may be considered a subclone of Ga 2 . The commonest clone of Pullorum is $\mathrm{Pu} 3$, which also appears to be globally distributed; $38(51 \%)$ of the 75 isolates of Pullorum represent $\mathrm{Pu} 3$ or the subclones $\mathrm{Pu} 3 \mathrm{a}, \mathrm{Pu} 3 \mathrm{~b}$, and $\mathrm{Pu} 3 \mathrm{c}$.

\section{Flagellin gene structure}

Spontaneous reversion to motility has not been observed in any strain of the non-motile salmonellae, ${ }^{2,24}$ but a transduction experiment reported by Lederberg and Edwards ${ }^{25}$ demonstrated that a strain of Gallinarum carried at least that part of a $\mathrm{fliC}$ gene specifying the same phase 1 flagellar antigenic determinants (epitopes $\mathrm{g}, \mathrm{m}$ ) as strains of Enteritidis. We found complete $\mathrm{AiC}$ genes in all nine strains of the non-motile salmonellae sequenced, and, moreover, the genes of strains of $\mathrm{Ga} 3, \mathrm{Ga} 4$ and $\mathrm{Ga} / \mathrm{Pu} 1$ were identical to the standard sequence of Enteritidis. However, a stop codon near the distal end of the gene (codon 495) was found in single strains of Ga 1, Ga 2 and Ga 2a (table VI), all of which were isolated in the Middle East.

The $f i C$ sequences of the Pullorum ETs differed from the standard sequence in having non-synonymous substitutions in either two or three codons (table VI). Because these changes occur in the central part of the gene in which epitopic variation is encoded, ${ }^{26-30}$ it is possible that, if expressed, the $f i C$ genes of strains of Pullorum would produce polypeptides with epitopes other than, or in addition to, $\mathrm{g}, \mathrm{m}$.

The inability of the non-motile salmonellae to express flagella cannot be attributed to loss or degeneration of the flagellin structural gene itself, which is intact in almost all strains. Hence, the genetic basis for non-motility remains to be determined; and because many genes are involved in the biogenesis of the flagellum, ${ }^{31}$ there are many ways in which the nonflagellate condition could have been achieved. The only other information available concerning the condition of flagellar genes in the non-motile salmonellae comes from comparative sequencing of $f g K$, which encodes the flagellar hook-associated protein 1 (HAP1) ${ }^{32,33}$ in single isolates of $\mathrm{Ga} 2, \mathrm{Pu} 3, \mathrm{Ga} / \mathrm{Pu} 1$, En 1, and laboratory strain LT2 of Typhimurium, representing Tm 1 (data not shown; J.L. and R.K.S., unpublished observations). The $f g K$ genes of Ga 2 and $\mathrm{Pu} 3$ are complete and more similar in sequence to the gene of En 1 than to that of Tm 1, but the sequences of all three non-motile strains have a stop codon at position 125 as a result of a $G \rightarrow T$ substitution; and the strain of $\mathrm{Ga} / \mathrm{Pu} 1$ also has a 336-bp deletion in the central part of the coding region of the gene.

Taken together, our findings indicate that loss of motility in the avian-adapted salmonellae occurred relatively recently in evolutionary time. The occurrence of the same stop codon in $f g K$ in all three 
lineages of the non-motile salmonellae strongly supports the hypothesis that they are monophyletic and that their most recent common ancestor was already non-motile. We suggest that the point mutations observed in $f i C$ and $f l g K$ accumulated after gene inactivation, when, as a consequence of mutation in another gene that inhibited flagellar biosynthesis, they were no longer subject to purifying selection. The original basis for ancestral non-motility may have involved a mutation in a gene affecting activity of the flagellar regulon,,$^{34.35}$ as, for example, the fliA gene, which has been shown in Typhimurium to encode a sigma factor specific for flagellar operons. ${ }^{35}$

Incidental to our main objective, we have confirmed the suggestion of Beltran et al. ${ }^{13}$ that the $f i C(\mathrm{~g}, \mathrm{~m})$ allele of En 2 was acquired by horizontal transfer and recombination from En 1 or some other lineage of Enteritidis. In ET, En 2 differs from En 1 at 12 of the 29 loci assayed (table III), yet in $f i C$ sequence it differs from En $\mathrm{I}$ and most other ETs of Enteritidis by single nucleotide substitutions in codons 53, 55 and 316 . Other examples of lateral transfer and recombination of $f i c$ genes have been identified. ${ }^{36,37}$

\section{Biotype groups}

Crichton and Old ${ }^{11}$ recognised that strains of Gallinarum are relatively homogeneous in biotype, whereas strains of Pullorum exhibit considerable biotype diversity. They distinguished two biotype groups of Pullorum, but four of the 36 strains examined by them could not be assigned to either group. By probing the chromosomal DNA of 12 isolates with a segment of a fimbrial subunit gene ( $\mathrm{P} 4$ probe), they concluded that the two groups also differ in restriction fragment length polymorphism pattern. However, this conclusion requires confirmation by analysis of a much larger sample of isolates, especially in view of our finding that the biotype groups are not cognate with ETs. Both Pu 2 and Pu 3 include isolates assigned to either of Crichton and Old's groups, and strains of $\mathrm{Ga} / \mathrm{Pu} 1$ are not assignable to either group. As demonstrated previously for clonal lineages of Salmonella Paratyphi $\mathrm{B}^{22}$ biotype characters evolve rapidly and convergently and, consequently, are of little value for phylogenetic analysis. Nevertheless, biotype characters that provide strain discrimination within serotypes may be invaluable for epidemiological studies. As intended, the biotype study of Crichton and Old $^{11}$ achieved type discrimination among strains of Gallinarum and Pullorum and, at the same time, indicated that an understanding of the evolutionary history of the non-motile salmonellae was likely to be achieved only by analysis of variation at the molecular level.

$\mathrm{Ga} / \mathrm{Pu} 1$ is in overall genetic character closer to ETs of Gallinarum than to those of Pullorum. Phenotypically, it is Pullorum-like in giving positive results in tests for gas production and for decarboxylation of ornithine; and genotypically, it resembles Pullorum in having the $\mathrm{MDH}^{3}$ and $\mathrm{AP}^{5}$ alleles. Unfortunately, we have no information on either the hosts or the type of disease caused by strains of $\mathrm{Ga} / \mathrm{Pu} 1$.

\section{Phylogenetic relationships between the non-motile salmonellae and enteritidis}

The neighbour-joining tree shown in fig. 1 places the ETs of Gallinarum, Pullorum and Gallinarum/ Pullorum near those of Enteritidis (excluding En 2), with which they share the somatic antigen profile 1,9 , 12. Inasmuch as we have not determined the multilocus enzyme genotypes of all the many serotypes of Salmonella subspecies I, we cannot definitively conclude that Enteritidis is the closest extant relative of the nonmotile salmonellae, but the available evidence is sufficient to establish a fairly close relationship. This conclusion is strongly supported by the identity or close similarity of the sequences of the $f i C, f g K$, and gnd genes in the non-motile salmonellae and Enteritidis En 1. Hence, we hypothesise that the non-motile salmonellae evolved from an Enteritidis-like ancestor that was motile and had a broad host range that included birds; in other words, a clonal lineage genetically and ecologically similar to En 1 .

In biochemical characters, Gallinarum and Pullorum differ markedly from one another and from Enteritidis, ${ }^{7,11}$ but variation in these phenotypic traits is likely to reflect differential adaptive modification rather than phylogenetic relationship.

\section{Evolution of the non-motile salmonellae}

Based on the results of our genetic analysis, we have developed a hypothetical evolutionary scenario for the origin and radiation of the non-motile salmonellae (fig. 3). This interpretation, which assumes that lineages have diverged solely by mutation, without lateral transfer and homologous recombination of genetic material, is a hypothesis that may be tested as new data become available.

A0 is the postulated most recent common ancestor of the ETs of Enteritidis (excluding En 2) and those of the non-motile salmonellae. In multilocus enzyme genotype (henceforth, MEG), A0 was similar to En 1, and its $f i C$ sequence (henceforth, FS) was the standard one. Al is the hypothetical most recent common ancestor of the ETs of the non-motile salmonellae. That the $\mathrm{Ga}, \mathrm{Pu}$ and $\mathrm{Ga} / \mathrm{Pu} 1$ ETs are monophyletic was initially suggested by our observation that they share three enzyme loci alleles $\left(\mathrm{PGI}^{5}, \mathrm{NP}^{3 \cdot 2}\right.$ and $\mathrm{THD}^{2}$ ) that are unique or rare among the salmonellae (table III). Subsequently, this inference was confirmed by the discovery of a shared stop codon at position 125 in the $f g K$ genes of strains of all three lineages of the non-motile salmonellae. In our hypothesis, a single mutational event in an Enteritidis-like ancestor inactivated the flagellar structural genes, following which they diverged through the accumulation of neutral mutations. This interpretation is one reason our scen- 


\section{A. Enzyme loci allele changes}

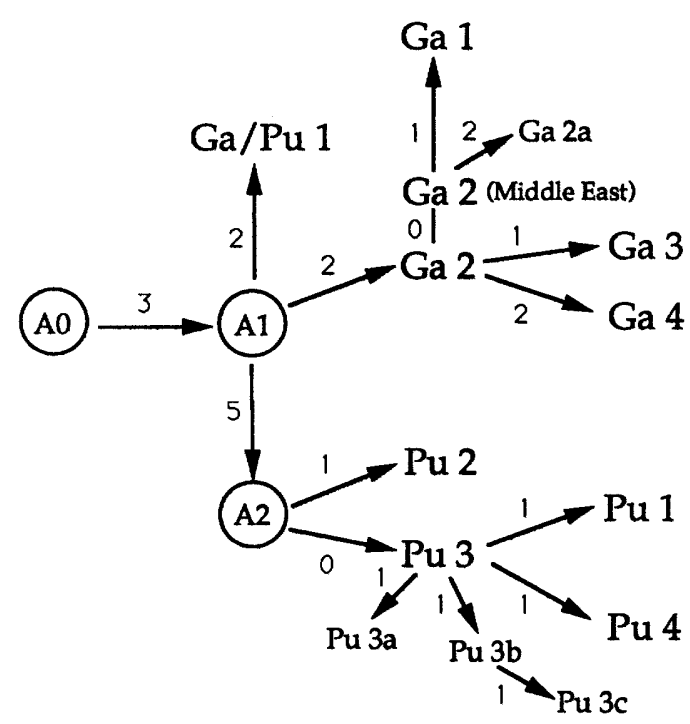

B. fliC nucleotide changes

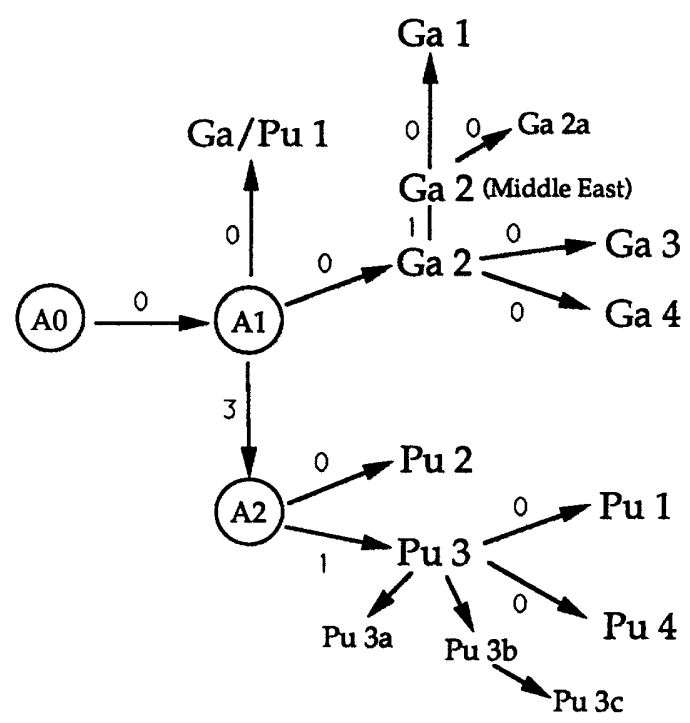

Fig. 3. Hypothetical evolutionary scenario for the ETs of the nonmotile salmonellae (see text). The $f i C$ genes of $\mathrm{Pu} 3 \mathrm{a}, \mathrm{Pu} 3 \mathrm{~b}$ and $\mathrm{Pu} \mathrm{3c}$ were not sequenced.

ario does not invoke recombination, despite evidence that recombination of $\mathrm{fiC}$ in the motile salmonellae is a major mechanism by which new serotypes arise. ${ }^{37}$ Because $\mathrm{fliC}$ is not expressed in the non-motile salmonellae, it is not subject to either purifying selection or selection favouring new flagellin epitopes. Consequently, recombinant genotypes of $f i C$ or other flagellar genes can achieve high frequency only through genetic drift. We assume that recombination events occur with low frequency and are not required to explain the evolutionary radiation of the non-motile salmonellae shown in fig. 3.

Also consistent with a monophyletic interpretation is the similarity in size $(85 \mathrm{~kb})$ and structure of the virulence plasmids of Gallinarum and Pullorum ${ }^{38-40}$ and the absence in strains of both biotypes of intact
23S ribosomal RNA (data not shown), a condition caused by the excision (without religation) of a small intervening sequence in the course of rRNA maturation. ${ }^{41}$ In Enteritidis, the virulence plasmid is much smaller ( $64 \mathrm{~kb}$ ), and most ${ }^{42}$ or all (data not shown) of the 23S rRNA is intact. Also, the non-motile salmonellae have type 2 fimbriae rather than the type 1 fimbriae expressed by Enteritidis ${ }^{43}$ and most other salmonellae. ${ }^{11}$

Ancestor A1, which had retained the standard FS of A0, was already non-motile and probably was also host-adapted to birds, although host restriction may have been less severe than in the extant clones of the non-motile salmonellae. From A1, three lineages diverged. First, $\mathrm{Ga} / \mathrm{Pu} 1$ arose by changes in $\mathrm{MEG}$ at two loci, $\mathrm{ACO}^{4}$ and $\mathrm{CAT}^{4}$, while the $\mathrm{FS}$ remained unmodified. Second, the lineage leading to the clones of classical Gallinarum first gave rise to $\mathrm{Ga} 2$ through two $\mathrm{MEG}$ changes, $\mathrm{MDH}^{7}$ and $\mathrm{AP2}{ }^{0}$. The FS remained unmodified in some geographic populations of $\mathrm{Ga} 2$; but in the population in the Middle East, a $\mathrm{C}$ to T substitution converted codon 495 to a stop codon. Subsequently, Ga 1 was derived from this Ga 2 population through a MEG mutation to $\mathrm{CAT}^{2}$, but without change in FS, and subclone Ga $2 \mathrm{a}$ arose from $\mathrm{Ga} 2$ by null mutations at AP1 and AL2, both of which produce phenotypes that are convergent with those of the ETs of Pullorum. Elsewhere, Ga 2 gave rise to Ga 3 by a $\mathrm{CAT}^{4}$ mutation and to $\mathrm{Ga} 4$ by mutations to $\mathrm{HEX}^{5}$ and $\mathrm{G}_{6} \mathrm{P}^{5}$. Third, $\mathrm{A} 1$ also gave rise to $\mathrm{A} 2$, the postulated most recent common ancestor of all Pullorum ETs, by the accumulation of five changes in MEG $\left(\mathrm{ACO}^{2 \cdot 5}, \mathrm{LGG}^{4}, \mathrm{GT}^{2}, \mathrm{AP}^{0}\right.$ and $\mathrm{AL2}{ }^{\circ}$ ) and non-synonymous substitutions in codons 91 and 339 and a synonymous substitution in codon 316 of the $f i C$ gene.

From ancestor $\mathrm{A} 2, \mathrm{Pu} 2$ evolved by $\mathrm{MEG}$ mutation to $\mathrm{G}_{6} \mathrm{P}^{2 \cdot 5}$, without change in FS. The derivation of $\mathrm{Pu} 3$ from A2 involved only a non-synonymous nucleotide substitution in codon 431 of $f i C$. Subsequently, Pu 3 gave rise to $\mathrm{Pu} 1$ by a mutation to $\mathrm{PGM}^{5}$ and to $\mathrm{Pu} 4$ by mutation to $\mathrm{NP} 1^{4 \cdot 9}$, with FS remaining unchanged. Subclones $\mathrm{Pu} 3 \mathrm{a}$ and $\mathrm{Pu} 3 \mathrm{~b}$ were each derived from Pu 3 by single null mutations at GLU and NP1, respectively; and subclone $\mathrm{Pu} 3 \mathrm{c}$ later arose from $\mathrm{Pu} 3 \mathrm{~b}$ by an additional null mutation at AP2.

This scenario postulates a total of 24 MEG mutations, six of which involve parallel change in separate lineages, $\mathrm{CAT}^{3}$ to $\mathrm{CAT}^{4}$ in both $\mathrm{Ga} / \mathrm{Pu} 1$ and $\mathrm{Ga} 3$ and mutations to $\mathrm{AP} 1^{\circ}$ and $\mathrm{AL} 2^{\circ}$ in $\mathrm{Ga} 2 \mathrm{a}$ and $\mathrm{A} 2$, the most recent common ancestor of the Pullorum ETs. For evolution of the $\mathrm{fliC}$ gene, five nucleotide substitutions (none parallel) are postulated.

An implication of this scenario is that a relatively rapid rate of evolution in both enzyme genotype and $\mathrm{fliC}$ sequence occurred between A1 and A2. Perhaps this was associated with the development of close hostadaptation to birds, which may have occurred earlier in the Pullorum lineage than in the lineages leading to the Gallinarum and $\mathrm{Ga} / \mathrm{Pu} 1$ clones. The fact that very 
different diseases are caused by strains of classical Gallinarum and Pullorum is consistent with the notion of independent development of host-adaptation.

A further implication of the scenario is that a lineage identical (or nearly so) in $\mathrm{fliC}$ sequence and very similar in enzyme genotype to ancestor $\mathrm{A} 0$ has persisted to the present time; this is represented by the globally predominant En 1 clone of Enteritidis. This lineage has given rise to a number of distinctive clones, including a dozen or so that are classified as Enteritidis because there has been no change in $\mathrm{fliC}$ and several that have acquired amino acid substitutions modifying the flagellin epitope profile from $\mathrm{g}, \mathrm{m}$ and are, consequently, classified in the Kauffmann-White scheme as distinct serovars. An example is Dublin, with flagellin epitope profile $\mathrm{g}, \mathrm{p}$ but only a minimal

\section{References}

1. Ewing WH. Edwards and Ewing's identification of Enterobacteriaceae, 4th edn. New York, Elsevier Science. 1986 : 181-318.

2. Le Minor L. Salmonella Lignieres 1900,389 . In: Krieg NR Holt JG (eds) Bergey's manual of systematic bacteriology, vol 1. Baltimore, Williams and Wilkins. 1984: 428-458.

3. Le Minor L, Popoff MY. Antigenic formulas of the Salmonella serovars, 5th edn. Paris, WHO Collaborating Centre for Reference and Research on Salmonella, Institut Pasteur. 1988: 1-146.

4. Pomeroy BS. Fowl typhoid. In: Hofstad MS, Barnes HJ, Calneck BW, Reid WM, Yoder HW (eds) Diseases of poultry, 8th edn. Ames, Iowa State University Press. 1984: 79-91.

5. Snoeyenbos GH. Pullorum disease. In: Hofstad MS, Barnes HJ, Calneck BW, Reid WM, Yoder HW (eds) Diseases of poultry, 8th edn. Ames, Iowa State University Press. 1984 66-79

6. Timoney JF, Gillespie JH, Scott FW, Barlough JE. (eds) Hagan and Bruner's microbiology and infectious disease of domestic animals, 8th edn. Ithaca, NY, Comstock Publishing Associates. 1988: 74-88.

7. Blaxland JD, Sojka WJ, Smither AM. A study of Salm. pullorum and Salm. gallinarum strains isolated from field outbreaks of disease. J Comp Pathol 1956; 6: 270-277

8. Cox NA, Williams JE. A simplified biochemical system to screen Salmonella isolates from poultry for serotyping. Poult Sci 1976; 55: 1968-1971.

9. Guinée PAM, Van Leeuwen WJ. Phage typing of Salmonella. In: Bergan T, Norris JR (eds) Methods in microbiology, vol 11. London, Academic Press. 1978: 157-191.

10. Lilleengen K. Typing of Salmonella gallinarum and Salmonella pullorum by means of bacteriophage. Acta Pathol Microbiol Scand 1952; 30: 194-202.

11. Crichton PB, Old DC. Salmonellae of serotypes Gallinarum and Pullorum grouped by biotyping and fimbrial-gene probing. $J$ Med Microbiol 1990; 32: 145-152.

12. Selander RK, Caugant DA, Ochman H. Musser JM Gilmour MN, Whittam TS. Methods of multilocus enzyme electrophoresis for bacterial population genetics and systematics. Appl Environ Microbiol 1986; 51 : 873-884.

13. Beltran P, Musser JM, Helmuth $R$ et al. Toward a population genetic analysis of Salmonella: genetic diversity and relationships among strains of serotypes $S$. choleraesuis, $S$. derby, S. dublin, S. enteritidis, $S$. heidelberg, $S$. infantis, $S$. newport, and S. typhimurium. Proc Natl Acad Sci USA $1988 ; 85: 7753-7757$

14. Wilson K. Preparation of genomic DNA from bacteria. In: Ausubel FM, Brent R, Kingston RE et al. (eds) Current protocols in molecular biology, vol 1 . New York, Wiley. $1990 \cdot 24.1-2.45$

15. Smith NH, Selander RK. Sequence invariance of the antigen- difference in enzyme genotype from En $1^{44}$ (fig. 1). Like Gallinarum and Pullorum, Dublin is strongly host-adapted (but to cattle rather than birds), and it is noteworthy that substantial proportions of isolates of the globally distributed clone Du 1 isolated in North America and Europe in recent years are non-motile, although the condition is apparently reversible. ${ }^{44}$ In Dublin, we may be witnessing an early stage in the permanent evolutionary loss of the flagellum, a process that has already occurred in the avian-adapted nonmotile salmonellae.

We thank Dr $\mathbf{R}$. Helmuth for providing strains; Ms J. M Gearhart, Ms P. P. Ho, and Ms S. A. Plock for assistance in the laboratory; and Ms K. E. Ferris for serotyping and biotyping. This research was supported by Grants AI-22144 (to R.K.S) and AI24566 and AI-00964 (to T.S.W.) from the National Institutes of Health.

coding central region of the phase 1 flagellar filament gene (fiC) among strains of Salmonella typhimurium. J Bacteriol $1990 ; 172$ : 603-609.

16. Saiki RK, Gelfand DH, Stoffel S et al. Primer-directed enzymatic amplification of DNA with a thermostable DNA polymerase. Science $1988 ; 239$ : 487-491.

17. Higuchi RG, Ochman H. Production of single-stranded DNA templates by exonuclease digestion following the polymerase chain reaction. Nucleic Acids Res 1989; 17: 5865.

18. Reeves $P$, Stevenson $G$. Cloning and nucleotide sequence of the Salmonella typhimurium LT2 gnd gene and its homology with the corresponding sequence of Escherichia coli K12. Mol Gen Genet 1989 ; 217 : 182-184.

19. Nasoff MS, Baker HV, Wolf RE. DNA sequence of the Escherichia coli gene, gnd, for 6-phosphogluconate dehydrogenase. Gene $1984 ; 27: 253-264$.

20. Nei M. Molecular evolutionary genetics. New York, Columbia University Press. 1987: 1-512.

21. Saitou N, Nei M. The neighbor-joining method: a new method for reconstructing phylogenetic trees. Mol Biol Evol 1987; 4: $406-425$.

22. Selander RK, Beltran P, Smith NH et al. Genetic population structure, clonal phylogeny, and pathogenicity of Salmonella paratyphi B. Infect Immun 1990; 58: 1891-1901.

23. Selander RK, Beltran P, Smith NH et al. Evolutionary genetic relationships of clones of Salmonella serovars that cause human typhoid and other enteric fevers. Infect Immun 1990; 58: 2262-2275.

24. lino T, Lederberg J. Genetics of Salmonella. In: Van Oye E (ed) The world problem of salmonellosis. The Hague, Dr W. Junk. 1964: 111-142.

25. Lederberg J, Edwards PR. Serotypic recombination in Salmonella. J Immunol 1953; 71 : 232-240.

26. Frankel G, Newton SMC, Schoolnik GK, Stocker BAD. Intragenic recombination in a flagellin gene: characterization of the $\mathrm{Hl-j}$ gene of Salmonella typhi. EMBO J $1989 ; 8$ : $3149-3152$.

27. Joys TM. The covalent structure of the phase-1 flagellar filament protein of Salmonella typhimurium and its comparison with other flagellins. $J$ Biol Chem 1985; 260: 15758-15761.

28. Joys TM, Schödel F. Epitope mapping of the d flagellar antigen of Salmonella muenchen. Infect Immun 1991; 59. 3330-3332.

29. Wei LN, Joys TM. Covalent structure of three phase-1 flagellar filament proteins of Salmonella. J Mol Biol 1985; 186: 791-803.

30. Yamaguchi S, Iino $T$. Genetic determination of the antigenic specificity of flagellar protein in Salmonella. J Gen Microbiol $1969 ; 55$ : 59-74.

31. Macnab RM. Flagella. In: Neidhardt FC, Ingraham JL, Low KB, Magasanik B, Schaechter M, Umbarger HE (eds) Escherichia coli and Salmonella typhimurium. Cellular and molecular biology, vol 1. Washington, D.C., American Society for Microbiology. 1987: 70-83. 
32. Homma M, Kutsukake K, Hasebe M, Iino T, Macnab RM. Flg B, Flg C, Flg F and Flg G. A family of structurally related proteins in the flagellar basal body of Salmonella typhimurium. J Mol Biol 1990; 211: 465-477.

33. Homma M, De Rosier DJ, Macnab RM. Flagellar hook and hook-associated proteins of Salmonella typhimurium and their relationships to other axial components of the flagellum. $J$ Mol Biol 1990; 213: 819-832.

34. Kutsukake K, Ohya Y, Iino T. Transcriptional analysis of the flagellar regulon of Salmonella typhimurium. $J$ Bacteriol $1990 ; 172: 741-747$.

35. Ohnishi K, Kutsukake K, Suzuki H, Iino T. Gene fiA encodes an alternative sigma factor specific for flagellar operons in Salmonella typhimurium. Mol Gen Genet 1990; 221: 139-147.

36. Smith NH, Selander RK. Molecular genetic basis for complex flagellar antigen expression in a triphasic serovar of Salmonella. Proc Natl Acad Sci USA 1991; 88: 956-960.

37. Smith NH, Beltran P, Selander RK. Recombination of Salmonella phase 1 flagellin genes generates new serovars. $J$ Bacteriol 1990; 172: 2209-2216.
38. Barrow PA, Simpson JM, Lovell MA, Binns MM. Contribution of Salmonella gallinarum large plasmid toward virulence in fowl typhoid. Infect Immun 1987; 55: 388-392.

39. Barrow PA, Lovell MA. The association between a large molecular mass plasmid and virulence in a strain of Salmonella pullorum. $J$ Gen Microbiol 1988; 134: 2307-2316.

40. Barrow PA, Lovell MA. Functional homology of virulence plasmids in Salmonella gallinarum, $S$. pullorum, and S. typhimurium. Infect Immun 1989; 57: 3136-3141.

41. Burgin AB, Parodos K, Lane DJ, Pace NR. The excision of intervening sequences from Salmonella $23 \mathrm{~S}$ ribosomal RNA. Cell 1990; 60: 405-414.

42. Hsu D, Zee YC, Ingraham J, Shih L-M. Diversity of cleavage patterns of Salmonella 23S rRNA. J Gen Microbiol 1992; 138: 199-203.

43. Müller K-H, Trust TJ, Kay WW. Fimbriation genes of Salmonella enteritidis. J Bacteriol 1989; 171 : 4648-4654.

44. Selander RK, Smith NH, Li J et al. Molecular evolutionary genetics of the cattle-adapted serovar Salmonella dublin. $J$ Bacteriol 1992; 174: 3587-3592. 